\title{
Titel/Title: Against all odds: the 'loyalty' of small investors
}

Autor*innen/Author(s): Uwe Schimank

Veröffentlichungsversion/Published version: Postprint

Zeitschriftenartikel/Journal article

\section{Empfohlene Zitierung/Recommended citation:}

Schimank, Uwe (2011): Against All Odds: The „Loyalty“ of Small Investors. In: Socio-Economic Review, 9 (1), 107-135.

Verfügbar unter/Available at:

(wenn vorhanden, bitte den DOI angeben/please provide the DOI if available)

This is a pre-copyedited, author-produced version of an article accepted for publication in Socio-Economic Review following peer review. The version of record "Schimank, Uwe (2011): Against All Odds: The „Loyalty“ of Small Investors. In: Socio-Economic Review, 9 (1), 107-135." is available online at: https://doi.org/10.1093/ser/mwq023

Zusätzliche Informationen/Additional information:

The author can be contacted at: uwe.schimank@uni-bremen.de 


\section{Against all odds: the 'loyalty' of small investors ${ }^{\dagger}$}

The share of small investors leaving the financial market in autumn 2008 was no greater than in previous, smaller crises. Why is there no mass exodus at such junctures? Why do most small investors practice 'loyalty' instead of 'exit' (Hirschman)? Even more importantly, why do they enter the financial market at all since its 'hypercomplexity' exposes them to an experience of confusion and helplessness? Behavioural economics provides some partial answers, but they remain too abstract and ahistorical and give a very reductionist picture of decision-making. In reaction to this incomplete understanding of the 'loyalty' puzzle, I will present two important explanatory factors from sociological reasoning: collectively shared stories as reducers of 'hypercomplexity' in which small investors' decision-making is embedded, and the rebuilding of the welfare state, which forces more and more people to become small investors and stay in the market despite serious losses.

Keywords: capitalism, economic man, financial crisis, financial market, investment banking

JEL classification: G2 financial institutions and services, P1 capitalist systems, Z1 economic sociology

At the end of the 1990s, Nadler (1999) spoke of 'the rise of worker capitalism' in the USA, thus emphasizing the inclusion not only of the middle class but also of parts of the working class among stockholders. ${ }^{1}$ At that time, $43 \%$ of American

\footnotetext{
${ }^{\dagger}$ A first draft of this article was presented at the conference on 'Commonalities of Capitalism' organized by Wolfgang Streeck at Ringberg Castle in November 2009. I received many useful suggestions from other conference participants; in particular, I would like to thank Helen Callahan, who commented on my paper on that occasion.

${ }^{1}$ However, as Zola's (1976 [1891]) novel L'Argent graphically illustrates, investments from the lower class and the lower middle class were no quantité n'egligable on the financial market more than a hundred years ago. Accounts of historical financial market crises since the seventeenth century also show that the middle class was always considerably involved (Kindleberger and Aliber, 2005).
} 
households owned stocks or stock mutual funds, compared with only $19 \%$ in ( $~ \leftarrow$ p. 107) 1983 (Nadler, 1999, pp. 1, 3). In 2001, this rose to almost 52\%, with the median value of investments being $\$ 34300$ (Preda, 2009, p. 4). The 'new investor class' - as Brooke Harrington (2008, pp. 2 - 3, emphasis omitted) puts it'collectively poured hundreds of billions of dollars into the stock market'. More recent data for Germany show that, in the year 2000 , about $20 \%$ of the population owned stocks, whereas in January 2009, after several months of great turbulence on the financial market, only about 13\% remained stockholders (Leven, 2009). These data illustrate different national levels of inclusion in the financial market as well as the partial and temporary reversibility of the inclusion dynamics. However, a significant level of inclusion of small investors still exists today in all developed countries.

Yet the assertion that 'amateur investors are not marginal' on the financial market any longer (Harrington, 2008, p. 5) is debatable. Preda (2009, pp. $4-5$ ) reminds us that 'the rise in the number of individuals participating in financial investments' does not mean 'that contemporary financial markets are dominated by individuals and/or families'. On the contrary, 'since the late 1950s, the role of institutional investors has continuously increased.' On the one hand, these institutional investors use the money they collect from individuals, more and more of whom belong to the lower middle class and working class. On the other hand, what the investment and pension funds decide to do with this money is their decision alone, even though they work under a high level of collective pressure to earn a substantial return on investment; otherwise, small investors will turn to another fund (Windolf, 2005, p. 23). However, small investors know that they are not a coordinated collective actor but only an aggregate of millions of individual decision-makers whose decisions may and actually often do counteract each other. So, they are aware that, with each person acting on his or her own, their individual investment decisions make no difference at all. They are nothing but pawns in the game of finance. Their money is used, but how much control do they have over what each one of them gets out of it?

This awareness develops into an acute feeling of helplessness during periods of financial crisis, such as the one that started in autumn 2008. Would not it be an understandable, if not to say a natural reaction of small investors to withdraw their money immediately from this highly insecure place? In other words, why was there no mass exodus of small investors from the financial market on this 
occasion, no more than in smaller crises before? To be sure, the abovementioned data for Germany show that some small investors did indeed choose to leave the financial market quickly in favour of more traditional investment options such as a savings account, and the same applies to other countries as well. However, why did not many more or even all of them leave? To restate the question in Albert Hirschman's (1970) well-known typology, why do most small investors practise 'loyalty' instead of 'exit' even during financial market crises? $(\leftarrow \mathbf{p . ~ 1 0 8 )}$

Of course, financial market professionals-investment bankers or financial advisers - would claim that this widespread 'loyalty' of small investors is quite rational, that it is the best thing they can do. Admittedly, there is sometimes great turbulence on the financial market, but it has to be endured patiently because better times will definitely come again. However, such reasoning by professionals did not at all convince small investors in the autumn of 2008 or on similar occasions before. On the contrary, their 'loyalty' was accompanied by rather noisy 'voice' directed against-in their view-totally incompetent and greedy professionals who were now also perceived as downright liars. Thus, even if the professionals' assessment of the situation is right - as is still reflected by the hegemonic view of mainstream economics ${ }^{2}$-it cannot explain the small investors' behaviour.

To refer to another possible explanation, we could say that 'loyalty' is a result of one's hands being tied by formal rules. Yet this explanation is also not very convincing with respect to small investors. Only a small amount of their money is invested on a long-term basis, most kinds of investment are flexible within days, even hours, if necessary. Even in cases where investors as well as banks or funds agree explicitly that the invested money is consigned for several years, it is implicitly understood that such an agreement holds only when the usual circumstances govern the market. But the circumstances of a deep financial crisis are certainly unusual; the penalty fee for cashing in an investment prematurely is much less than the potential losses of doing nothing. Therefore, in a rational calculation, the considerable losses that most small investors have suffered already from the deep financial market crisis and have to fear for the near future

\footnotetext{
${ }^{2}$ For a spectrum of unorthodox views, however, see Minsky (1986), Mandelbrot and Hudson (2004), Kindleberger and Aliber (2005) or Frank (2009).
} 
outweigh by far the losses of a sudden exit.

As in other areas of economic decision-making where rationalist microeconomic explanations fail, behavioural economics is introduced to offer answers that rely mainly on cognitive and personality psychology. In the following, I will only briefly discuss the explanatory factors offered by this perspective for the widespread 'loyalty' among small investors, because most of them are rather well known by now. Even taken together, they provide insufficient explanations of the 'loyalty' puzzle. Their two main shortcomings are their ahistorical character and their subject-centred conceptualization of decision-making. Both shortcomings can be overcome by the introduction of relevant sociological factors. The theoretical exposition of such sociological factors is the main subject of this article. Thus, without denying the worth of economic and psycho- logical perspectives, I want to show that sociology makes an essential contribution to an adequate understanding of the small investors' 'loyalty'. $(\leftarrow$ p. 109)

I will start with a clarification of the situation of small investors from the analytical perspective of empirical and theoretical studies of 'real life' decisionmaking. ${ }^{3}$ It can be shown that the financial market exhibits 'hypercomplexity', which is a permanent source of confusion for those who have to make rational decisions. One would expect actors to leave such a highly uncomfortable place; however, most small investors stay. The first set of explanatory variables I will discuss are mental factors. After having given behavioural economics its due, I will turn to two explanatory variables suggested by sociological reflections of a small investor's situation. One variable — collectively shared stories - emphasizes the embeddedness of the small investor in intersubjective sense-making. The other - the rebuilding of the welfare state-positions the small investor in recent societal dynamics. Whereas the first sociological variable corrects a one- sided view of actors as socially disembedded decision-makers, the second one brings society back in as a historically specific entity.

Our empirical sociological knowledge about 'the world as seen by a small investor' is still very insufficient. We have, on the one hand, some rather superficial sociodemographic and attitudinal data from standardized questionnaires and

\footnotetext{
3 This is in contrast to the highly stylized concepts of the microeconomic rational-choice approach. For an overview, see March (1994) and Schimank (2005).
} 
statistics (for example, Wärneryd, 2001). They give a few interesting hints but, as is usually the case with this type of data, point out no causal mechanisms that underlie observed correlations. On the other hand, there are only very few sociological studies that dig deeper into the social context of small investors' decision-making. Aldo Legnaro, Almut Birenheide and Michael Fischer made qualitative interviews with small investors in Germany at the beginning of the new century, after the 'new economy' boom had busted (Legnaro et al., 2005). Harrington (2008) made participant observations and conducted interviews in investment clubs in the USA during the 1990s and revisited them in 2004. As far as I am aware, these are the only studies that feature a carefully designed and executed, qualitative empirical approach and achieve an in-depth under- standing of certain motives and practices of small investors. Legnaro et al. (2005) interpret their data from the perspective of recent 'governmentality studies'. Thus, becoming and being a small investor is seen as an important com- ponent of a new mode of subjectivity in post-Fordist capitalism. I will reconsider this view when I turn to the rebuilding of the welfare state. Harrington is mainly interested in collective decision-making in investment clubs, and in this context she becomes aware of the relevance of storytelling among small investors. I also use bits of empirical material from both studies to illustrate some of my theoretical arguments. Both studies, however, focus on active small investors. Thus, they deliver no empirical data about the majority of passive small investors who make $(\leftarrow$ p. 110) investment decisions only rarely and do not bother at all about their investments most of the time. However, this group is obviously very important if I am to explain the 'loyalty' puzzle; so it becomes imperative to include them in my reflections.

I should make clear from the beginning that this article is a theoretical exploration which-because of an enormous lack of sufficiently detailed empirical knowledge - tries to conceive an analytical perspective that is designed precisely for the purpose of inspiring further empirical research to provide this needed knowledge. Even if this research should revise or totally reject the perspective I propose, my efforts would have served the purpose of being fruitful stimulation for cumulative empirical research. 


\section{The 'hypercomplexity' of the financial market}

Seen from the perspective of studies of real life decision-making, investment decisions exhibit—just as any other decision — three dimensions of complexity with which a decision-maker has to come to terms (Schimank, 2005, pp. 121 171). First, there is the information dimension. A decision-maker has to do with more or less incomplete and more or less insecure information, both with respect to facts as well as causalities. Second, in the time dimension, a decisionmaker is aware of the fact that there is little time for making a decision, and what time there is is marked by deadlines, windows of opportunities about to close or problems that are becoming worse by the minute. Third, in the social dimension, a decision-maker realizes interdependencies between one's own decision and the activities of others. The success of what the decision-maker does depends on what the others are doing, or not doing. While these three dimensions of complexity are universal features of any decision, the relative weight of each of these dimensions varies with different kinds of decision. In emergency decisions - for instance, of aeroplane pilots or surgeons - the scarcity of time has top priority, whereas in decisions involving technical constructions, such as the building of an atomic reactor, the information dimension is the most relevant. In contrast to these two kinds of decision, investment decisions on the financial market confront the decision- maker, above all, with social complexity.

At first glance, this view does not fit the subjective experience of many investors, be they professional or small investors. ${ }^{4}$ After all, they permanently lament about how fast they have to make their decisions on a financial market which has become a 24-hour, worldwide, high-speed decision arena. Not hours, but $(\leftarrow \mathbf{p}$. 111) minutes, sometimes only seconds, count,,$^{5}$ and if a brilliant decision is made too late, this may be worse than an uninspired decision made in time. Investors also complain about the poor information base on which they must make their decisions. This applies to every single type of investment, such as a particular

\footnotetext{
${ }^{4}$ For small investors, see many vivid empirical illustrations in Legnaro et al. (2005, pp. 72-149, 168 $-220)$.

5 By now, about half of the total trade on the German financial market is executed by computers that buy huge amounts of stocks only for seconds to sell them again at a little higher price - the so-called algo-traders (Mohr, 2009).
} 
stock. Even if an investor carefully collects all the publicly available facts about a potential investment, he cannot be sure that there are no hidden yet decisive facts; and who causally understands the technical intricacies of many of the new financial instruments? ${ }^{6}$ Moreover, each object of investment has to be seen in comparison with alternatives, which may be more profitable (Harrington, 2008, pp. 36 - 40). This aspect of investment decision-making opens up an overwhelming horizon of facts and causalities that no one can master. Literally, thousands of possibilities appear on the screen, even if an investor restricts him- or herself to certain regions, certain branches of industry or certain financial instruments: a 'negative infinity', as Harrington (2008, p. 38) calls it, thereby evoking a term used by Georg Wilhelm Friedrich Hegel. In addition to traditional information systems connected to the financial market, from informal gossip to specialized newsletters, the new information technologies provide each investor with a degree of worldwide market transparency that in reality amounts to nothing but paralysing intransparency.

Thus, investors in general attribute the complexity of the decisions they have to make primarily to the time dimension and the information dimension. However, this is not just a superficial view of their situation but a delusion that hides the real kind of complexity with which they have to cope. The conventional view of the financial market supports this delusion. According to this view, the financial market is nothing but an instrument of the 'real economy' through which loans needed to increase the capital of a firm are acquired; in return, loan-givers get stocks of the firm (Lütz, 2008). Therefore, the value of a stock depends on the firm's standing in the 'real economy', and this, in turn, is determined by the relation of the supply of the goods the firm pro- duces, on the one hand, and the demand for these goods, on the other. Seen in this way, there is an intrinsic value of a stock, which is based ultimately on the relative utility of the respective goods. What the so-called 'fundamental analysis' of investment alternatives does is nothing but to uncover this intrinsic value with the use of manifold data on the global, national, branch and firm levels and to derive from the difference between this intrinsic value of $\mathrm{a}(\leftarrow \mathbf{p . ~ 1 1 2})$ stock and its current

\footnotetext{
6 Not even the bosses of the big banks, as they had to confess recently! See Frank (2009, pp. 152-185) for an overview of some of these instruments.
} 
price decisions about buying, keeping or selling it (Schmidt, 2001).

Of course, the supply of and demand for a firm's goods depend critically upon its competitors and its customers - in this sense the social dimension of complexity is present in 'fundamental analysis', and every investor on the financial market is aware of it. However, this is only the social complexity of the observed 'real economy', not of the financial market in which the investor-as an observerparticipates. 'Fundamental analysis' treats the social complexity of the 'real economy' as an important part of the information dimension of complexity, as facts an investor must take into account when making decisions. With respect to the financial market in which an investor acts, 'fundamental analysis' operates as if no other investor exists. This fiction works as long as stock prices do not deviate much from their intrinsic value - a state of affairs which 'fundamental analysis' postulates as the normal state of the financial market. Whenever a larger and longer lasting deviation occurs, this indicates, in the conventional view, either exogenous interventions into the 'real economy' or the financial market, for instance by the state, or temporary phenomena of 'herding' among investors. Only for such an exceptional 'irrational' state of affairs is it admitted that social complexity has an impact on the financial market and must be taken into account in investment decisions.

Yet there is a case to be made against this conventional view. Even if an investor on the financial market had plenty of time to collect information and make the necessary calculations, and even if this information base was as complete as possible in terms of facts and causalities, the complexity of the investor's decision would not be significantly reduced, because this complexity has a totally different origin. It evolves from the fact that not only Ego acts on the financial market but so do other investors ${ }^{7}$ who are making the same kind of decisions, and that all these decisions - including Ego's - interact. To put it in the extreme, this priority of the social dimension of complexity means that Ego's information level is ultimately irrelevant. The investor might be able to predict future price fluctuations of stocks perfectly on the basis of 'fundamental data', but this means nothing for the investor's investment decision because the overriding determinant of the dynamics of prices is other investors' predictions of these dynamics and their

${ }^{7}$ For the sake of argument, it can be supposed that they also are well informed and have plenty of time for their decisions. 
decisions based on these predictions. So what Ego really has to do to arrive at a good decision is to predict the effects of the predictions made by the others (Harrington, 2008, p. 42). ${ }^{8}$ To quote John Maynard Keynes's (1973 [1936], ( $\leftarrow$ p. 113) p. 156) well-known characterization of investment decisions: 'We have reached the third degree where we devote our intelligences to anticipating what average opinion expects the average opinion to be.'

Unlike the anticipation of tomorrow's weather, this task is not a 'game against nature' but a strategic game in the sense that the objects of Ego's anticipation are themselves anticipating subjects, too. In a 'game against nature', it is helpful to have more information and more time to reflect upon this information. But the social complexity confronting the investor on the financial market cannot be reduced by more information or more time because such situations in which actors mutually observe each other exhibit what Ekaterina Svetlova (2009, p. 187, my translation) calls 'hypercomplexity', ${ }^{9}$ in reference to Niklas Luhmann. This is not just the famous problem of double contingency in a dyad, which Talcott Parsons analyses as point zero of social life from which somehow social order must emerge (Parsons et al., 1951), but-as Keynes's for- mulation clearly expresses - a problem of mutual contingency of expectations within a triad. ${ }^{10}$ Ego observes others-Alteri and Tertii-observing each other, including Ego itself. Because these observations are the basis for decisions on all three sides, no one is able to make a rational decision. Ego's ability to decide rationally what to do depends on its ability to anticipate what the others will be doing; but the Alteri's ability to decide depends on its ability to anticipate the Tertii's decisions, and vice versa. So the double contingency among Alteri and Tertii produces an unsolvable

\footnotetext{
${ }^{8}$ This specific kind of social complexity exists not only on the financial market. The same general pattern of 'self-organization' (Müller-Benedict, 2000) can also be seen in a much more trivial phenomenon such as an early morning traffic jam caused by many people going to work by car. When you are stuck on a certain road at 7 a.m. day after day, you may reckon that you should perhaps start half an hour earlier or take a different route. But you are aware of the fact that many others are considering the same alternatives - so are these alternatives worth trying at all?
}

${ }^{9}$ Maital et al. (1986, p. 281, emphasis omitted) call the same phenomenon 'superrational', as seen from the perspective of the actor.

${ }^{10}$ Lindemann (2009, pp. 226-253) works on a general theory of social life that goes beyond the usual Ego-Alter dyads to emphasize the 'constitutive function of the third party' for all social phenomena. 
problem of rational decision- making for Ego.

Added to this is a crucial problem of timing. To put it simply: if Ego considers buying the stocks of a particular firm and-no matter how it assesses the firm's future itself - anticipates that, in the near future, many others will predict a bright future for the firm, Ego can conclude that many people will want to buy the firm's stocks; so they will become more scarce and, consequently, more expensive; accordingly, Ego should buy them now to sell them later for a higher price. The other way round, if Ego owns stocks of a firm and anticipates that the common view of the firm's future will soon become negative, it would be better to sell its stocks before many others do because then buyers of these $(\leftarrow \mathbf{p . 1 1 4})$ stocks will become scarce and prices will fall. In both situations, Ego's profit on the financial market depends on it being faster than many others in correctly anticipating the prevailing assessment and the decisions based on it. Thus, the competitive nature of investment decisions implies a race in which each investor wants to be among the first to reach a decision.

An actor who is expected to make a rational decision in a situation that poses a rationally unsolvable problem to him, which he nevertheless has to solve as soon as possible, has all reason to feel rather uncomfortable. He cannot avoid doing something ${ }^{11}$ — but he is totally confused about what to do. This is embarrassing even if the consequences of his actions are fine or at least not too bad because the actor remains uneasy about how long his decision will 'work'. Thus, although the actor is presently not in a high-cost situation, the risk that this could change in this direction is omnipresent. The 'hypercomplexity' becomes acutely painful when things then do indeed go wrong and the high-cost situation is actually present the extreme case being an investor who loses a lot of money during a long general decline of the financial market.

This explication of the 'hypercomplexity' of small investors' decision-making situations shows that their widespread 'loyalty' to the financial market is by no means self-evident even in good times. The first question in the puzzle about 'loyalty' is to ask why small investors are exposing themselves at all to this overall unpleasant cognitive 'bad opening' (Klapp, 1978)? Only after having found an

\footnotetext{
11 Even doing nothing counts as an activity because he could have acted; so the - positive or negative - consequences of doing nothing are attributed to him.
} 
answer to this question should we then ask why, not even the real harm of a serious loss of money — experienced by many small investors during a financial market crisis - brings about a rapid decline of 'loyalty'.

\section{2. 'Loyalty' despite 'hypercomplexity'}

Portraying an investor's situation on the financial market as 'hypercomplex' refers to the objective constellation of actors in which the investor is involved. Although this objective situation may be characterized as highly unpleasant, the intersubjective and, shaped by this to an important degree, the subjective definition of the situation may differ. Supposing that an actor cannot endure a highly unpleasant situation for a long time and certainly will not linger if exit options exist, it must be asked how the actor, both alone and together with the other actors involved, can experience the situation as one which is at least tolerable.

When we start to look for answers to this question, it is important to realize that 'loyalty' could, on the one hand, be the result of a deliberate decision. Based on some kind and degree of rational calculation, this would be a $(\leftarrow$ p. 115) meta-decision to stay in the decision arena of the financial market instead of totally giving up this involvement. On the other hand, 'loyalty' could just as well be the result of a small investor's ongoing practice of making investment decisions. From other areas of decision-making, we know that meta-decisions are rare events that usually only occur when the first-order decision-making is in big trouble. Therefore, I suspect that the small investors' 'loyalty' is also not the result of some troubleshooting meta-decision but just the opposite of it. They do not perceive their investment decisions as sufficiently troublesome to provoke a meta-decision. If this is true, we should look for factors which reduce the subjective complexity of the financial market for them. I begin with mental factors emphasized by behavioural economics and then turn to the two social factors that are my major concern here.

\subsection{Mental factors}

Behavioural economics depicts financial market actors in general and small 
investors in particular as actors driven by a limited set of very simple cognitive heuristics and psychological needs, ${ }^{12}$ with the latest fad being 'animal spirits' (Akerlof and Shiller, 2009). Through a number of studies of this kind, we have been introduced to some mental factors that can explain small investors' 'loyalty' to a certain extent. ${ }^{13}$ I will briefly consider the four most relevant ones here.

First, there is the 'disposition effect' as a special case of the 'sunk cost effect' (Goldberg and von Nitsch, 2004 [1999], pp. 92 - 98). With respect to a situation where an investor loses money in a particular investment, this factor amounts to an inclination not to cancel this investment. A cancellation would mean to write off the losses and give up the hope that this investment could develop positively in the future to an extent that would not only make up for the losses but ultimately yield a substantial return. Only if the latter is the case, if this investment eventually earns a handsome return, is it worthwhile to pursue this option compared with other options, including that of spending the money for immediate satisfaction. The 'disposition effect' usually plays a larger role, the greater the share of the investment is of the investor's total capital. Writing off E100 is easier than writing off $E 10000$, if this is half of $(\leftarrow \mathbf{p . ~ 1 1 6})$

the money you possess. On the contrary, the 'sunk cost effect' even urges the investor to throw good money after bad, to use the other half of his capital to try to save this loss-making investment, with the probable result that he loses all his money (Goldberg and von Nitsch, 2004 [1999], pp. 128-129). This is not just simple 'loyalty' but can amount to 'loyalty' on a ruinous scale. Writing off losses would also mean, second, that the investor admits to himself and to others that he made a mistake or at least that he is not success- ful. This confession is a threat to very basic components of one's identity. The person realizes in this high-cost situation that his ability to master his life is seriously limited; his 'locus of control' shifts from internal to external (Rotter, 1966;

\footnotetext{
12 A still highly useful overview of behavioural economics in general is given by Rabin (1998); for a recent review, see DellaVigna (2009). Goldberg and von Nitsch (2004 [1999]) apply the findings of behavioural economics to investment decisions, especially those of small investors. For a critical assessment of the achievements of behavioural economics, see Etzioni et al. (2010).
}

13 Since these factors are part of the mental constitution of human beings, they shape professional investors' decision-making as well, but perhaps, due to training, to a somewhat lesser degree. 
Fiske and Taylor, 1991, pp. 86-88). In addition, he may also feel guilty if the money he loses is not just his own but belongs at least symbolically to others who put their trust in him, such as his wife or his children. As long as the actor sticks to his loss-incurring investment, he can avoid these highly negative feelings about himself and maintain a self-perception of having things under control (Goldberg and von Nitsch, 2004

[1999], pp. 140 - 142).

The mental factors discussed up to this point are reinforced, third, by the powerful general tendency of 'self-enhancement' exhibited by most people (Fiske and Taylor, 1991, pp. 212-216). In addition to the very positive assessment people have of themselves, which is markedly above-average in the most important respects, they overestimate their own competence compared with the average competence level. ${ }^{14}$ For instance, a great majority of us claim to be much better drivers than the average person. Yet logically this can only be true if the distribution of car-driving competencies was very strongly skewed, which is certainly not the case. This mental predisposition decreases a person's de facto risk aversion..$^{15}$ Thus, many drivers secretly believe that speed limits are needed because of the other drivers but are unnecessary restrictions of their own superior driving competence. The translation to the financial market is obvious: the average small investor simply thinks that she is at least a little bit smarter than the rest. This selfdelusion facilitates an otherwise self-contradictory co-existence of two conflicting assessments in many small investors' minds: on the one hand, they admit that the financial market in general repeatedly experiences great turbulence and is therefore dangerous terrain. On the other hand, investors each consider themselves capable of maintaining sufficient control over their own investment decisions because they are convinced of their superior experience and special sources of information. In this way, self-enhancement easily produces $(\leftarrow \mathbf{p}$. 117) an illusion of control that underlines 'loyalty' even in highly dangerous times (Goldberg and

\footnotetext{
${ }^{14}$ For a general psychological model, see Frey (1988).

15 It is important to keep in mind that their de facto risk-aversion may differ from their articulated inclination to bear risks.
} 
von Nitsch, 2004 [1999], pp. $153-156){ }^{16}$

By this point, at the latest, the similarity becomes noticeable between small investors and persons gambling in a lottery. Beyond a superficial resemblance that common knowledge often uses to criticize small investors, ${ }^{17}$ there is, indeed, a deeper mental factor common to both activities. This fourth mental factor has not been discussed until now in behavioural economics but could easily be included in its analytical framework. The empirically proven fact is that a substantial number of those who are gambling in a lottery on a regular basis act on 'markets for dreams', as Mark Lutter (2010, forthcoming) concisely expresses it (Beckert and Lutter, 2007). Most of them are aware of the probabilities of winning-but these gamblers reverse the burden of proof against all odds: in their minds, nothing and nobody can rule out the possibility that they are the very special 'chosen' person who will one day win the jackpot. It is this attitude that offers them time and again an opportunity for daydreaming about how it will be 'when I win the lottery'. ${ }^{18}$ What is true about consumption in the modern economy in general (Campbell, 1987; Beckert, 2010) and about gambling in particular is also a mental driving force of small investors. With their investments, they buy a place in a base camp for daydreaming. Instead of speculating and worrying about the ups and downs of some stock or fund, they use their ownership of it as a starting point for colourfully detailed fantasies about better days to come after they have made a good profit. In a sense, investment losses are even better for such daydreaming because this downturn postpones the moment when this profit is realized; and what Campbell (1987, p. 90) notes pertaining to goods in general applies also to the purchases small investors might finally buy with their profits: 'reality can never provide the perfected pleasures encountered in day-dreams'. The joy of anticipation always outdoes the reality. So 'this sweet sick- ness'-as Patricia

\footnotetext{
16 Interestingly, psychological research shows that 'mildly and severely depressed individuals appear to be less vulnerable to this illusion of control' (Fiske and Taylor 1991, p. 214). The question is whether suffering from depression has the positive effect that one assesses oneself more realistically, or the other way round, one becomes depressed as a consequence of gaining a realistic view of oneself.
}

${ }^{17}$ Accordingly, small investors would very probably deny this comparison. See some of the statements in Legnaro et al. (2005, pp. 138 - 142).

18 To quote the title of a revealing song by Camper van Beethoven on the album 'Key Lime Pie' (1989). 
Highsmith calls daydreaming with regard to one of her fictional heroes - may cost small investors a lot of money in terms of losses instead of returns; but the psychic gains with respect to their own identity, in particular with their plans and ideas for a better future life, often outweigh these losses. In this way, daydreaming is another mental factor that can explain why small investors show 'loyalty' to the financial market. $(\leftarrow$ p. 118)

As this brief description shows, these factors are built-in mental boundaries of rational decision-making. They all distort the perception of gains and losses with respect to amounts and probabilities in the direction of 'loyalty'; moreover, in the same direction, they satisfy very basic psychological needs of people with respect to their self-perception. The other side of the coin is that, as boundaries, these mental factors reduce the 'hypercomplexity' of the financial market and enable small investors to make decisions in the first place. ${ }^{19}$ For instance, the overestimation of one's own abilities may be the decisive impulse to start dealing with a very difficult investment decision, instead of trying to avoid it altogether as a consequence of a realistic assessment of one's chances to come to a satisfactory solution. This proof of one's ability to make a decision, in turn, postpones the metadecision and brings about 'loyalty' instead.

Behavioural economics convincingly shows the explanatory relevance of these mental factors. Yet, even taken together, they remain a highly incomplete explanation of the 'loyalty' puzzle for at least two reasons, to which I turn here. First, these mental factors are highly abstract, ahistorical variables. The disposition effect, for instance, existed among Stone Age people as well, and it applies not only to investment decisions but to all areas of decision-making. Thus, these mental factors gain explanatory power only when they are properly specified by contextual factors. Second, behavioural economics gives us a very reductionist picture of decision-making. It neglects the intersubjective embeddedness of decision-making. In both respects, a sociological perspective points out additional essential answers to the 'loyalty' puzzle. ${ }^{20}$

\footnotetext{
${ }^{19}$ What should be mentioned but cannot be discussed here is that all of these mental boundaries are in certain respects 'simple heuristics that make us smart' (Gigerenzer et al., 1999). They not only bring about a decision where otherwise the actor would be totally paralysed, the decision reached also entails at least some minimum level of rationality that has to be specified for each of these factors.
} 


\subsection{Social factors}

In the following, my focus will be on two very different kinds of social factors, both of which seem to be rather important frames for the definition small investors have of their decision-making situation: for one, collectively shared stories about particular investments or the investment market in general, and for another, an individual small investor's economic situation as it is shaped by the contemporary rebuilding of the welfare state. Whereas stories are part of the cultural orientations of a small investor's decision-making, the rebuilding $(\leftarrow \mathbf{p}$. 119) of the welfare state refers to financial pressures and restrictions of his decision-making.

2.2.1 Collectively shared stories To Parsons and other social theorists, the task of dealing with double contingency is mainly a thought experiment that serves to clarify the functions of those familiar and ubiquitous social mechanisms that produce and reproduce social order, such as institutionalized norms, hierarchical power or path dependency. In most social situations, the complexity of double contingency is already reduced by such mechanisms so that actors have no particular problem to coordinate their own actions with the actions of others, including rational decision-making.

When we examine investment decisions, most of the time professional financial market actors are not paralysed by 'hypercomplexity'. What the 'new economic sociology' has demonstrated in many studies to be true for actors in 'realeconomy' markets (Beckert, 2007, pp. 9 - 13) is also true for professional financial market actors. To a significant degree, they are embedded: first, in institutional regulations that are enforced hierarchically by the state or by professional communities, second, in social networks, and third, in shared cultural orientations. Taken together, these embedding structures considerably reduce the social complexity. It is true that, for some decades now, legal norms have been deliberately reduced as the most obliging social structures of embeddedness during a long period of political deregulation to give professional financial market

among different small investors. To give an obvious example, the use of investments for daydreaming should be more prominent among the not-so-well-off members of society; thus, social inequality appears to be a determinant of the relevance of this mental factor. 
actors more room to manoeuvre in their global investment decisions; and this increased scope of action has been used for a ceaseless invention of new financial instruments, a development which has had the aggregate effect of a sustained loss of market transparency (Frank, 2009) or, in other words, a marked increase of complexity confronting the actors. However, 'soft' but effective social structures of embeddedness function among professional investors. ${ }^{21}$ These investors have common cultural orientations originating from extended professional training and frequent interaction with each other. In addition, professional investors maintain decentralized but still close social networks with each other as well as with many actors of the 'real economy'.

Thus, professional financial market actors are part of a community of practice that has established for itself a shared knowledge base through dense, direct and indirect communication. By no means does this imply that the intersubjective reduction of the 'hypercomplexity' of the financial market among professional investors always depicts the objective situation correctly. However, professional investors feel more self-confident and trust their shared views. Furthermore, it is well known that, to a considerable degree, financial markets work according $(\leftarrow$ p. 120) to 'self-fulfilling prophecies' (Merton, 1948). If a critical mass of investors believes in a certain investment, this can help to bring about its success. Thus, even if pro- fessional investors are initially wrong with regard to the objective situation, their joint willpower may prove them right in the end.

Small investors, in contrast, usually have no professional training for the financial market; most of them, at best, read some popular books or articles on the subject. Small investors get most of their information from the general news media, additionally sometimes from special journals and the Internet (Goldberg and von Nitsch, 2004 [1999], p. 205). The large majority of them are not members of a community of practice in which an exchange of experiences and information occurs regularly from which everybody learns, gets tips for lucrative investments and, most importantly, builds up trust in their own ability to make rational investment decisions..$^{22}$ The very limited amount of time small investors

\footnotetext{
${ }^{21}$ See Abolafia (1996) and Preda (2009) for many relevant observations.

22 An exception is the case of small investors who are members of investment clubs (Harrington2008, pp. 73-142).
} 
have to devote to the financial market is far from the least important factor preventing their involvement in relevant communities and net- works. Therefore, typical small investors are much less embedded in those kinds of social structures that buffer professional investors against the financial market's 'hypercomplexity'. However, what often sufficiently compensates for this lack of professional communities and networks are collectively shared stories. ${ }^{23}$

Let us begin with the largest group of small investors, namely, those who do not decide for themselves whether, when and how much to trade in certain stocks or bonds, but delegate such decisions more or less to professional advisers, often at their home banks. Formally, such advisers recommend what these passive small investors should do about their investments - in fact, very often small investors simply follow this advice without much consideration of their own, not the least because they have no idea what their options are or what they could do instead. Basically, these small investors have one meta-decision to make: which adviser shall they trust?

This question of trustworthiness is the variant of social complexity most prominent in principal-agent relations: how can a principal, such as a small investor, be sure that his agent - the adviser - is able and willing to act in the principal's best interest (Ebers and Gotsch, 1998, pp. 209-225)? Without systematic empirical evidence, I suspect that rather superficial signals of the agent's trustworthiness suffice to reassure the principal in the relationship between small investors and advisers. Such signals are, on the one hand, the general reputation of the $(\leftarrow \mathbf{p}$. 121) respective bank or investment company, including the image it presents in its advertisements and public relations, and the individual adviser's personal image and reputation. In these respects, common practices of 'impression management' are relevant (Goffman, 1956). On the other hand, the story an adviser uses to present a particular decision probably ends up being the most important factor (Akerlof and Shiller, 2009, pp. 51 -56).

Stories are narrative accounts of something happening. They present these occurrences as a whole, which in temporal terms has a beginning and an end; both

\footnotetext{
23 Such stories are also part of the professional investors' communities and networks. But to them, stories are just one among several mechanisms that reduce the financial market's 'hypercomplexity', whereas small investors rely critically upon stories.
} 
are connected by an account of how the specific state of the world at the beginning is transformed into a different - sometimes, however, into the same - state of the world at the end (Schapp, 1953; Lübbe, 1960/61, pp. 98-114). ${ }^{24}$ Comparable with a scientific explanation by a mechanism (Mayntz, 2005) but not necessarily with a claim of generalization, stories explicate a dynamic from an initial state to an end state by pointing out the sometimes rather intricate interplay of causes resulting in this dynamic. With respect to decision-making under conditions of high complexity, Harrington (2008,

p. 48) notes that "stories can thus be seen as cognitive "glue", allowing humans to engage in complex judgment tasks by imposing a narrative structure on fragmented segments.' Thus, first, stories provide actors, such as small investors, with overall coherence. They are given an understanding of the decision matter they have to deal with. Second, a story that guides decision-making has to have an 'entrance' that opens the door of participation to the respective decision-maker and, in order to generate the motivation to participate, must offer prospects of a 'happy end' for the small investor (Harrington, 2008, p. 70). ${ }^{25}$ Sometimes, the decision-maker is required to take on a specifically designated role in the story's script. At the least, she must be given a handle in the complex mechanism presented to her that helps her to bring about the happy end for herself.

A convincing story of this kind - best backed by some evidence from the media (Clark et al., 2004) — explains with suggestive plausibility why a particular stock, or the stock market in general, is going to rise; if the prognosis can be backed by some data that appear to prove the start of such a promising development, the small investor's initial sceptical questions are easily turned into a more or less enthusiastic motivation to invest. She becomes content with and actually grateful for stories such as the one about the technological innovation potential $(\leftarrow \mathbf{p}$. 122) that gave rise to the 'new market' of the late 1990s, or the story that has been

\footnotetext{
24 Compared with this rather precise formal conceptualization of stories by phenomenological philosophy, the use of the term by White (1992) and others in economic sociology (Mützel, 2009) is quite sloppy. They tend to label any kind of account involving relevant information as 'stories', especially knowledge gathered from mutual observation among economic actors.

${ }^{25}$ However, a 'happy end' may mean nothing more than an actor being able to prevent the worst from happening.
} 
circulating for some time now about the unparalleled opportunities for growth in the Chinese and Indian economies. Finally, effective story lines and modes of presentation are those that heed or, even better, strategically apply the simple cognitive heuristics that greatly influence decision-making - such as the framing effects that every professional investor is well acquainted with by now (Goldberg and von Nitsch, 2004 [1999]).

In addition, many stories relevant for decision-making on the financial market, as elsewhere, are anchored in the personal identity of the decision-maker. As Harrington $(2008$, pp. 48, 70) points out, 'when individuals buy a stock, they are not only buying a financial instrument that they hope will make them a profit; they are also buying a story. And in buying the story of the company, they are buying a story about themselves ... . the stocks investors own become part of the story they tell the world about themselves.' This is most evident if investors buy the stocks of companies whose products and corporate identity fit to their personal identities, be it in religious, political, ecological, health care or other life- style matters (Harrington, 2008, pp. 64-69; Säve-Söderbergh, 2010). For example, a German small investor asserts: 'Well, Siemens, that's again somewhat questionable because they have branches such as atomic energy, arms ...' (Stopper, Interview 2). ${ }^{26}$ But the same use of investment decisions for the construction, presentation and maintenance of one's identity can be found if something like a 'love affair' takes place over time between an investor and stocks initially bought only for reasons of short-term profitability but then held onto through thick and thin over the years.

In these ways, stories produce an embeddedness of the small investor by means of cultural orientations; in the case of a passive investor, these are brought home to him through a professional adviser. ${ }^{27}$ However, small investors do not believe every story they are told by their advisers; the latter are, on the contrary, subjected to a subtle pressure to adjust to the small investors' perception of the financial

\footnotetext{
${ }^{26}$ This example is taken from a series of interviews a student of mine (Silke Stopper) conducted for her Magister thesis. I use some material from two of her interviews. All the quotations have been translated by me.
}

27 In Zola's (1976 [1891]) novel, these diverse aspects of stories with respect to the persuasion of investors in general and small investors in particular were already pointed out very graphically. 
market. As Robert Shiller (2002, p. 24) observes: 'Clients often expect the professionals to invest in accordance with certain fads.' To a decision-maker with little information about the subject and no time to study the choices, the most credible choice is the one that other investors in a comparable situation have made. Accordingly, passive small investors are strongly inclined to be what Elster $(1989$, pp. $203-204)$, in his reflections $(\leftarrow$ p. 123) about the mobilization for collective action, calls 'mass participationists'. They simply imitate what many others do.

Of course, that a small investor's trust can be so easily won by storytelling ${ }^{28}$ is a phenomenon that correlates with the degree to which the investor inherently finds investment decisions to be a burden. Although he knows that these are high- cost decisions with regard to his personal future, he does not understand much about them and feels nothing but bewilderment when someone attempts to explain the financial market to him. So it is anything but entertaining for him to spend leisure time interpreting what stock market news mean for his own investments. He even has difficulties in assessing post hoc the relative success of those decisions based on the recommendations of his adviser. After all, even considerable losses can be interpreted as the successful avoidance of much worse; indeed, this may be true. Therefore, this kind of small investor simply lacks any realistic standards that he himself perceives as convincing. As a conse- quence of all this confusion, he wants to spend as little time as possible with these tiresome decisions.

Turning now to the smaller group of active small investors, we find that the picture essentially does not change but shows some interesting additional facets. Active small investors are engaged in a continual observation of the financial market and their own portfolio, collect relevant information on a more systematic basis and decide basically on their own what to buy and sell. Since active investors make an extra effort, compared with passive small investors, especially in terms of time spent, why do they not just remain passive and rely on professional advisers instead? It is because they are confident that they do better by deciding on their own - more precisely, better to such a degree that their considerable effort pays off.

Most active small investors seem to have started as passive ones, and a frequent

${ }^{28}$ To put it more drastically: the small investor is such an easy prey for charlatans - see again Zola. 
motivation to become active apparently is a loss of trust in professional advisers. After a while, their advice does not produce the returns to which the small investors aspire or may even incur losses. A typical example is someone who gets a proposal from his savings bank one day to invest part of his money in one of the bank's funds instead of earning only the low interest from his savings account. He accepts, but after a time comes to the conclusion: 'Nothing went really wrong. But it was not really good, either. Anyhow, was it a loss? I forgot about it. It just wasn't good enough.' And his reaction becomes: 'Well, I said these funds have no value. I better take selected stocks which you yourself like better. I mean, then you yourself can decide quicker.' (Stopper, Interview 1). Note that this change from 'I' to the generalized 'you' signifies this small investor's effort to categorize his decision-making as reasonable although the mentioned criterion $(\leftarrow$ p. 124) to make investments 'which you yourself like better' sounds at first quite idiosyncratic and not very rational. What it really expresses is that the loss of trust in professional advisers has turned into an attitude of 'trust yourself!'

Other examples from the study of Legnaro et al. (2005, pp. 126-148) are more explicit with regard to active small investors' self-confidence. Small investors all frankly admit that, in contrast — as they perceive it — to big banks or investment companies, they are unable to influence either the firms whose stocks they hold or the dynamics of the financial market as a whole. In addition, they see clearly that professional investors have much more inside information and can react much faster to sudden market turbulences than they. Thus, as decision-makers, they consider themselves to be in a rather disadvantaged position on the financial market. Still, these small investors are convinced that they exercise at least 'predictive secondary control' in the sense that they adapt to a world they cannot change, a world whose causal regularities they can learn and anticipate over time so that they are able to take advantage of its course (Fiske and Taylor, 1991, p. 202). As they see it, they are able to predict the story line of what will happen very early, just as an experienced reader of a detective novel knows after a few pages who the murderer is.

They view information as the crucial ingredient in their decision-making, the ingredient that they think makes their success the result of more than just luck: 'It is still very hard work to acquire knowledge, to inform yourself, to develop your strategy, again, it is damn hard work, it's not just luck.' This is a firm conviction: 'I do believe that if you study it, it's more predictable how a rate of exchange devel- 
ops.' Then they can profit from this knowledge: 'So you can easily, with a little skill, generate above-average returns on capital. Not much luck involved; it's sufficient to take a look at the chart ....' A minute later the same person admits: 'Well, you have to examine some stocks a little more carefully and for a longer period of time' (all quotations from Legnaro et al., 2005, pp. 142, 143, 145, 146, my translation). Another small investor felt, 'as a mechanical engineer', he was able to 'assess companies that are well positioned'. Later on he repeats: 'Well, I know these companies, certainly sympathy has some part i it' (Stopper, Interview 2). In the same vein, someone else states: 'Well, real estate funds and such things where you never know what is behind it. I never took that into consideration. But, for example, there are solar-cell producers, you can take a look what are they producing, where are they based You always have to know who is behind it' (Stopper, Interview 1). In other words, unconnected bits of information, such as statistical figures alone, are not sufficientyou need to have a convincing story to feel comfortable with a decision for a particular investment.

What many of these active small investors assume they can accomplish in this way is to 'swim with the stream' and to hitch a 'free ride' with the trend: 'I can't $(\leftarrow$ p. 125) change or influence anything, but if I manage to jump on the right running board at the right moment, then I can earn something.' Which 'running boards' are the right ones is revealed to active small investors, in contrast to passive ones, in stories that they assume are not known to everybody. Active small investors believe they belong to small circles with exclusive knowledge. Some claim that they are early discoverers of emerging stories. Against this insistence on having an early feeling for an incipient majority move - to know the majority before it has formed - other small investors explicitly point out that one must have 'a good nose' for the directions the stocks will really take, no matter what the majority thinks: 'Of course, the only thing that I do, can do, is arrive at my opinion contrary to all the TV analysts, newspaper analysts ...' . Another investor emphasizes, with reference to one of his decisions, that 'many people I knew didn't do that, they bought quite differently' (all quotations from Legnaro et al., 2005, pp. 130, 140, 142, 146, my translation). Still another small investor reflects about one of his decisions: 'Well, then I think, they weren't right last time' so it's alright' for him to decide against the trend (Stopper, Interview 1). 
Such small investors are co-producers of the stories that inspire their investment decisions (Harrington, 2008, pp. 51 - 60). In fact, an active small investor may go with the majority sometimes and do the opposite at others, and whenever this person fails, she can always tell herself that she could have done otherwiseas she had successfully in the past. In this way she is able to maintain a selfperception in which, in principle, she is able to control the fate of her money. Single instances of failure do not negate her perceived general capacity for control; they just point out to her that control is not total but limited.

Oscillating between purposive optimism and low-key rationality in the various aspects described, these active small investors, as well as the passive ones discussed before, are able to maintain their sense of 'actorhood' (Meyer and Jepperson, 2000) as rational decision-makers; this is the result of collectively shared stories reducing the 'hypercomplexity' of the financial market. As long as this sense of 'actorhood' prevails, it contributes decisively to the small investors' 'loyalty'.

\subsubsection{Rebuilding the welfare state Paradoxically, the second social factor that} accounts for the 'loyalty' of more and more small investors today is an important restriction of their 'actorhood' with regard to investment decisions. Although they are not formally tied to their investments, they cannot afford leaving the financial market because the profits they hope to earn there are funds they urgently need. In this sense, they are in a high-cost situation without exit options. There is a crucial difference between such small investors for whom the financial market is a place where they may earn some extra money and those whose future life chances depend critically on profits from their investments. Many of $(\leftarrow \mathbf{p}$. 126) those who bought stocks in the decades before the 1990s were in a low-cost situation with good exit options. They invested money that they did not need at the moment and-even more importantly-could do without in their future life plans. They chose stocks because the return on capital was higher than that from alternative investments, such as a savings account or government bonds, but only if this higher return was not too risky. For instance, a German small investor who bought his first stocks in 1961 remembered that his motive was 'the simple discovery that you don't get wealthy with eight hours - with an eight hour job'. Asked whether he 
had harboured the hope of becoming rich, he said: 'No. I never had this idea. I just wanted, in the sixties, to learn how the whole thing works' (quoted in Legnaro et al., 2005, pp. 81 - 82, my translation). This statement of modest aspirations combined with a certain curiosity seems to be quite typical for that time. Besides members of the upper class who always were active on the stock market, some middle-class people took a chance there, as one strategy among others to become a little better off. If they failed, they did not have a problem but just accepted a loss they could afford. After such incidents, some turned to other ways of investing their money, not the least by returning to the traditional savings account, while others tried stocks yet again.

Then, in the 1990s, a 'stock market populism' (Harrington, 2008, pp. 11 - 14) started in the USA and in many other Western countries. It was triggered by the favourable opportunity structure of the so-called new market consisting of the technologically innovative IT and media industries. In some Western countries, such as Germany, the boom of these stocks coincided with the crest of the wave of capital formation among the middle classes after World War II. Because no war or deep global economic crisis had interrupted steady income growth across the board, people were looking for opportunities to invest considerable amounts of money profitably (Deutschmann, 2005, p. 80, 2008). Whereas in the 1960s, as noted above, members of the middle class who became small investors saw themselves as a clever minority, in the 1990s the opposite public perception emerged: only fools stayed away from the financial market.

Someone who started investing in the financial market during those boom years stated: 'Well, everyone, including me, got infected by the boom at the time. By all the profits colleagues earned .. . A Another one said: 'It was a real joy, I calculated in a half-year, three-quarters of a year rhythm how much money I possessed then and how much I had owned before. And it's simply a great feeling. When you don't do anything and the money simply grows.' A third person expressed even higher hopes: 'Well, like a virgin who finds herself pregnant, I found myself with all this sudden profit, starting in '97, '98, '99, and for a short time that was really .. . , well, you thought if it goes on like this I'll stop working with 30. so you joked a bit about it and said if it goes on $(\leftarrow \mathbf{p . ~ 1 2 7})$ like this I will stop working 
with 40 , or with 30 . But seriously, I never thought about it or believed in it'. Finally, when asked if he had really believed he would become rich, one person who made substantial profits at that time answered: 'No, it was more to fulfil nice wishes. .. . Went to London, and we went into a fancy clothing store .. . If you have it, who cares? You can afford it' (quoted in Legnaro et al., 2005, pp. 83, 85, 89 , my translation). Just as the money earned by the avant-garde small investors of the 1960s, these returns earned on the new market were still just additional income, certainly nice to have but of no existential importance. If the returns declined or became too risky, these small investors could turn away from the financial market and were able to suffer their losses without critical harm done to their future life plans.

However, in many Western countries, the number of investors with such exit options has declined substantially since the 1990s. For the USA, Harrington (2008, p. 19, emphasis omitted) notes 'that the surge of new investors .. . during the 1990s was due in large part to the changing social contract between labor and management, which made investing an increasingly necessary source of income.' Since then, more and more individuals have been forced to try their luck as small investors, in Germany and other countries as well; the pressure to be successful on the financial market, in the sense of earning high returns, has increased for many people, too. First, they are told that their own pensions are not safe, so that whatever they receive will not be enough for a decent living in their old age. This is an existential threat. ${ }^{29}$ Second, they are told that they will have to invest a lot of money in the education of their children - not only university tuition, as was recently introduced in Germany, but fees for the attendance of private schools or for private coaching, not to mention pre-school preparation: all this to make sure that one's own sons and daughters will not be predestined losers on the future job market. This threat also becomes a mighty impulse to act. ${ }^{30}$

\footnotetext{
${ }^{29}$ See Harrington (2008, pp. 19-21, 180-182) for the USA. Bulmahn (2003) shows for Germany that many persons are prepared now to invest in their old-age pension; see also Legnaro et al. (2005, pp. $58-71)$. However, they are not prepared to run the risk of losing their money in this investment. See Tigges (2009) for the situation of American middle-class elderly people after the crash of autumn 2008, and Zola's (1976 [1891]) novel for the desperate situation of retired persons from the lower class who lost the little money they had in the described financial market crisis.
}

30 See Knop's (2009) journalistic report about the German middle class in the current crisis. 
Behind these threats, which pressure individuals to become and remain small investors, is a massive rebuilding of the welfare state in all Western countries along a so-called neo-liberal line. ${ }^{31}$ To make a long but well-known story $(\leftarrow \mathbf{p}$. 128) short: by the time the general public finally realized that the 'short dream of ever- lasting prosperity' (Lutz, 1984, my translation), which lasted from the mid1950s until the mid-1970s, had crumbled, ongoing macroeconomic problems had brought about a chronic and increasing fiscal crisis of public finances (Streeck and Mertens, 2010). The result has been an economizing of welfare production from basic services of social security, such as unemployment benefits and old-age insurance, to health care, education or public housing. What had for- merly been standard provision has turned into a luxury that one cannot afford any longerand as a compensation for the lack of money coming from the state, individual provision is now being called for. Even more, if one is to take charge of one's own fate, then it becomes necessary to develop what Ulrich Bröck- ling (2007, my translation) calls an 'entrepreneurial self'. Instead of counting on solidarity within the family, the trade unions or the welfare state, a person must rely on self-help and take responsibility for one's own destiny, including personal failures such as job loss, chronical illness or a criminal conviction. Whereas the 'providential state' (Thibaud 1985, p. 136) had once helped in cases of individual hardship and had compensated, more or less, for disadvantages caused by birth or bad luck, now the spirit of entrepreneurship has become predominant. For the welfare state, this means that its ultimate goal, towards which all services are sup- posed to be reorganized, is the 'activation' of its clients' potential for self-help. Accordingly, the term 'social' has been redefined: no longer referring to the state taking care of its citizens, it now means that citizens are required to take care of themselves. Being 'social' now means not living at the state's-i.e. the taxpayers'-expense (Lessenich, 2008).

Using Michel Foucault's concept of 'governmentality', Legnaro et al. (2005, pp. 25 - 58) see the involvement of more and more individuals in the financial market as a logical extension of this 'entrepreneurial self'. To become a small

\footnotetext{
${ }^{31}$ For empirical overviews and divergent theoretical and political interpretations, see Luhmann (1981), Bourdieu and Accardo (1993), Bourdieu (1998), Kaufmann (1997), Lessenich (2003, 2008), Butterwegge et al. (2007) and Münch (2009).
} 
investor in order to earn - if you are lucky - the money you need for a decent pension and a good education for your children is, for a growing number of individuals, the natural way of life or 'how these things are done', to adopt Berger and Luckmann's (1966, p. 77) telling expression for a reified institutional order. For more and more small investors, the impulses to defend their own future living standard and that of their children already dominate other motives and will become even more pressing in the future in the face of the probable ongoing reduction of corresponding welfare state services. The depiction of small investors as people who want to get rich quickly and effortlessly is outdated. Thus, their entrepreneurial spirit is not at all heroic but, on the contrary, almost fatalistic.

On the one hand, an increasing number of small investors seem to be quite modest in the sense that they do not aspire for riches but would be highly satisfied if they could secure a certain standard of living for their own future and that of their children. On the other hand, this modesty nevertheless implies a demand for $(\leftarrow \mathbf{p . 1 2 9})$ steadily growing returns as long as the actual, perceived or anticipated decline of the welfare state, accompanied by an unstable economy and an insecure job market, continues. For quite some time now, small investors have been part of the real-world 'people's capitalism': for them, investment in the financial market is not an opportunity for everybody to benefit from the wealth pro- duction of capitalism but is an enforced inclusion in the financial market driven by the need to avoid future financial hardship. As Harrington (2008, p. 149) observed when, in 2004, she revisited her empirical sample of small investors from the 1990s, 'the most surprising finding was that all of them were still investing.' Asked why they had not left the financial market after the 'new economy' bubble burst, 'many said they had no choice but to keep buying stocks'. One respondent put it this way: 'Where else are we going to put our money? In the mattress?' Harrington (2008, p. 152) concludes: 'They invest by default—out of a sense that they lack good alternatives.'

When a massive financial loss occurs, as it did for many in autumn 2008, the impulse to take flight becomes irresistible - but that is exactly what has become impossible! The high-cost situation of many small investors forbids any thought of exit. So their 'loyalty' is compulsory. To endure this, it is often accompanied by a mental functionalist fallacy that Deutschmann (2006, p. 190, my translation) aptly calls the small investor's faith in a "'natural right" of return on capital'. Of course, this perceived material need predisposes them also to believe the promises 


\section{9}

made by banks and investment companies that these expectations can be reached. The compulsory 'loyalty' makes them gullible believers in the stories told to them about particular investments and the future chances on the financial market in general. Whenever such promises fail, many small investors do not adapt their aspiration level to more realistic expectations; on the contrary, they exhibit a desperate courage, which is actually the final psychological reason for the highly resilient persistence in unrealistic beliefs about the return on capital they can achieve. Because they have lost money and time, they are forced to earn even more money in even less time. Just as persons with critical diseases often fall prey to quacks, these sorely afflicted small investors are liable to trust the most dubious promises of getting rich in six years, 30 days or even 24 hours.

\section{Conclusion}

I choose to stop at this point to avoid any theoretical reflections that are too speculative. As I said at the beginning, the aim of this article was to elaborate, as far as is possible without a solid empirical foundation, important sociological contributions to the 'loyalty' puzzle of small investors. These theoretical ideas do not directly compete with what we have already known from behavioural $(\leftarrow \mathbf{p}$. 130) economics. Neither do both perspectives contradict each other, making only one of them true in the end, nor does a sociological perspective declare as irrelevant what behavioural economics shows. Mental factors and the two social factors that were my focus here can be combined in a fruitful way to understand better why so many small investors enter the financial market, although it confronts them with 'hypercomplexity', and stay there even when they suffer, time and again, serious financial losses. Collectively shared stories reduce this 'hypercomplexity' for them, and many small investors nowadays have de facto no viable exit options. To dig deeper into these two social factors requires empirical work, the first of which should be predominantly qualitative approaches just like the work of Legnaro et al. (2005) and Harrington (2008). Careful comparisons of contrasting cases with respect to both variables and their combinations as well as biographical studies of small investors' long-term involvement and decision-making practices would be especially useful. A better understanding of their 'loyalty' is not only interesting with regard to small 
investors and their situation but has implications in society at large. Even if small investors remain subordinate actors on the financial market—just 'cannon fodder', in the wars of the really important actors, as Legnaro et al. $(2005$, p. 20) put itthey may express the confusion and frustration experienced there with more power in the political arena, and this may raise problems of legitimacy for governance or even the political order in general, in addition to any possible repercussions on the financial market. $(\leftarrow$ p. 131)

\section{References}

Abolafia, M. (1996) Making Markets—Opportunism and Restraint on Wall Street,Cambridge, MA, Harvard University Press.

Akerlof, G. A. and Shiller, R. J. (2009) Animal Spirits: How Human Psychology Drives the Economy, and Why It Matters for Global Capitalism, Princeton, NJ, Princeton University Press.

Beckert, J. (2007) Die soziale Ordnung von Märkten, MPIfG Discussion Paper 07/6, Cologne, Max Planck Institute for the Study of Societies.

Beckert, J. (2010) The Transcending Power of Goods. Imaginative Value in the Economy, MPIfG Discussion Paper 10/4, Cologne, Max Planck Institute for the Study of Societies.

Beckert, J. and Lutter, M. (2007) 'Wer spielt, hat schon verloren? Zur Erklärung des Nachfrageverhaltens auf dem Lottomarkt', Kölner Zeitschrift für Soziologie und Sozialpsychologie, 59, $240-270$.

Berger,P.L. and Luckmann, T.(1971[1966]) The Social Construction of Reality: ATreatise in the Sociology of Knowledge, Harmondsworth, Penguin.

Bourdieu, P.(1998) Gegenfeuer: Wortmeldungen im Dienste des Widerstands gegen die neoliberale Invasion, Konstanz, Universitäts Verlag Konstanz.

Bourdieu, P. et al. (1997 [1993]) Das Elend der Welt: Zeugnisse und Diagnosen alltäglichen Leidens an der Gesellschaft, Konstanz, Universitäts Verlag Konstanz.

Bröckling, U. (2007) Das unternehmerische Selbst, Frankfurt/M, Suhrkamp.

Bulmahn, T. (2003) 'Zur Entwicklung der privaten Altersvorsorge in Deutschland, Vorsorgebereitschaft, Vorsorgeniveau und erwartete Absicherung im Alter', Kölner Zeitschrift für Soziologie und Sozialpsychologie, 55, 29-54.

Butterwegge, C., Lösch, B. and Ptak, R. (2007) Kritik des Neoliberalismus, Wiesbaden, VS.

Campbell, C. (1987) The Romantic Ethic and the Spirit of Modern Consumerism, Oxford, Blackwell.

Clark, G. L., Thrift, N. and Tickell, A. (2004) 'Performing Finance. The Industry, the Media and Its Image', Review of International Political Economy, 11, 289 -310.

DellaVigna, S. (2009) 'Psychology and Economics. Evidence from the Field', Journal of Economic Literature, 47, 315 - 372.

Deutschmann, C. (2005) 'Finanzmarkt-Kapitalismus und Wachstumskrise'. In Windolf, P. (ed) Finanzmarkt-Kapitalismus: Analysen zum Wandel von Produktionsregimen, Wiesba- 
den, VS, pp. $58-84$.

Deutschmann, C. (2008) 'Keynes und die Rentiers. Warum die Überflussgesellschaft bis heute auf sich warten lässt'. In Deutschmann, C. (ed) Kapitalistische Dynamik-Eine gesellschaftstheoretische Perspektive. Wiesbaden, VS, pp. 175 -192.

Deutschmann, C. (2008) Der kollektive 'Buddenbrooks-Effekt'. Die Finanzmärkte und die Mittelschichten, MPIfG Working Paper 08/5, Cologne, Max Planck Institute for the Study of Societies.

Ebers, M. and Gotsch, W. (1998) 'Institutionenökonomische Theorien der Organisation'. In Kieser, A. (ed) Organisationstheorien, Stuttgart, Kohlhammer, pp. 199 - 251.

Elster, J. (1989) The Cement of Society: A Study of Social Order, Cambridge, Cambridge University Press.

Etzioni, A., Piore, M. J. and Streeck, W. (2010) 'Discussion Forum II: Behavioral Economics', Socio-Economic Review, 8, 377 - 398.

Fiske, S. T. and Taylor, S. E. (1991) Social Cognition, New York, NY, McGraw-Hill. Frank,

S. (2009) Die Weltvernichtungsmaschine: Vom Kreditboom zur Wirtschaftskrise, Saarbrücken, Conte.

Frey, B. S. (1988) 'Ein ipsatives Modell menschlichen Verhaltens. Ein Beitrag zur Ökonomie und Psychologie', Analyse und Kritik, 10, 181 - 205.

Gigerenzer, G. and Todd, P. M. and the ABC Research Group (1999) Simple Heuristics That Make Us Smart, Oxford, Oxford University Press.

Goffman, E. (1973 [1956]) Wir alle spielen Theater, München, Piper.

Goldberg, J. and von Nitsch, R. (2004 [1999]) Behavioral Finance: Gewinnen mit Kompetenz, München, FinanzBuch Verlag.

Harrington, B. (2008) Pop Finance: Investment Clubs and the New Investor Populism, Princeton, NJ, Princeton University Press.

Hirschman, A. O. (1970) Exit, Voice and Loyalty: Responses to Decline in Firms, Organizations, and States, Cambridge, MA, Harvard University Press.

Kaufmann, F.-X. (1997) Herausforderungen des Sozialstaates, Frankfurt/M, Suhrkamp.

Keynes, J. M. (1973 [1936]) The General Theory of Employment, Interest and Money, London, Macmillan Publishers.

Kindleberger, C. and Aliber, R. (2005) Manias, Panics, and Crashes: A History of Financial Crises, Hoboken, NJ, Wiley.

Klapp, O. E. (1978) Opening and Closing: Strategies of Information Adaptation in Society, Cambridge, Cambridge University Press.

Knop, C. (2009, April 11) 'Beten und arbeiten', Frankfurter Allgemeine Zeitung, p. 13.

Legnaro, A., Birenheide, A. and Fischer, M. (2005) Kapitalismus für alle: Aktien, Freiheit und Kontrolle, Münster, Westfälisches Dampfboot.

Lessenich, S. (ed) (2003) Wohlfahrtsstaatliche Grundbegriffe: Historische und aktuelle Diskurse, Frankfurt/M., Campus.

Lessenich, S. (2008) Die Neuerfindung des Sozialen: Der Sozialstaat im flexiblen Kapitalismus, Bielefeld, Transcript.

Leven, F. J. (2009) Finanzkrise und Abgeltungssteuer: Drastischer Rückgang der Fondsanleger, DAI-Kurzstudie 1/2009, Frankfurt am Main, Deutsches Aktieninstitut, accessed at http://www.dai.de/internet/dai/dai-2-0.nsf/dai_publikationen.htm on September 7, 
2010.

Lindemann, G. (2009) Das Soziale von seinen Grenzen her denken, Weilerswist, Velbrück.

Lübbe, H. (1972 [1960/61]) “"Sprachspiele" und "Geschichten”: Neopositivismus und Phänomenologie im Spätstadium'. In Lübbe, H. (ed) Bewusstsein in GeschichtenStudien zur Phänomenologie der Subjektivität, Freiburg, Rombach, pp. 81-114.

Lütz, S. (2008) 'Finanzmärkte'. In Maurer, A. (ed) Handbuch der Wirtschaftssoziologie, Wiesbaden, VS, pp. $341-360$.

Luhmann, N. (1981) Politische Theorie im Wohlfahrtsstaat, München, Olzog.

Lutter, M. (2010, forthcoming) Märkte für Träume: Die Soziologie des Lotteriespiels, Frankfurt a. M./ New York Campus Verlag.

Lutz, B. (1984) Der kurze Traum immerwährender Prosperität: Eine Neuinterpretation der industriell-kapitalistischen Entwicklung im Europa des 20. Jahrhunderts, Frankfurt/M., Campus.

Maital, S., Filer, R. and Simon, J. (1986) 'What Do People Bring to the Stock Market (Besides Money)? The Economic Psychology of Stock Market Behavior'. In Gilad, B. and Kaish, S. (eds) Handbook of Behavioral Economics. Vol. B: Behavioral Macroeconomics, Greenwich, CT, JAI Press, pp. $273-307$.

Mandelbrot, B. and Hudson, R. L. (2004) The (Mis)Behavior of Markets-A Fractal View of Risk, Ruin, and Reward, New York, NY, Basic Books.

March, J. G. (1994) A Primer on Decision Making: How Decisions Happen, New York, NY, Free Press.

Mayntz, R. (2005) 'Soziale Mechanismen in der Analyse gesellschaftlicher MakroPhänomene'. In Schimank, U. and Greshoff, R. (eds) Was erklärt die Soziologie?, Berlin, LIT, pp. $204-227$.

Merton, R. K. ([1948]1995) 'Die self-fulfilling prophecy'. In Merton, R. K. (ed) Soziologische Theorie und soziale Struktur, Berlin, de Gruyter, pp. 399 - 413.

Meyer, J. W. and Jepperson, R. L. (2000) 'The "Actors" of Modern Society: The Cultural Construction of Social Agency', Sociological Theory, 18, 100 - 120.

Minsky, H. P.(1986) Stabilizing an Unstable Economy, New Haven, CT, Yale University Press.

Mohr,D. (2009, November 14) Ohne menschliches Antlitz, Frankfurter Allgemeine Zeitung, p. 15.

Müller-Benedict, V. (2000) Selbstorganisation in sozialen Systemen, Opladen, Leske \& Budrich.

Münch, R. (2009) Das Regime des liberalen Kapitalismus: Inklusion und Exklusion im neuen Wohlfahrtsstaat, Frankfurt/M., Campus.

Mützel, S. (2009) 'Koordinierung von Märkten durch narrativen Wettbewerb'. In Beckert, J. and Deutschmann, C. (eds) Wirtschaftssoziologie, Wiesbaden, VS, pp. 87 - 106.

Nadler, R. (1999) The Rise of Worker Capitalism, Policy Analysis No. 359, Washington, DC, Cato Institute.

Parsons, T. et al. (1951) 'Some Fundamental Categories of the Theory of Action: A General Statement'. In Parsons, T. and Shils, E. (eds) Toward a General Theory of Action, Cambridge, MA, Harvard University Press, pp. 3 - 29.

Preda, A. (2009) Framing Finance: The Boundaries of Markets and Modern Capitalism, 
Chicago, IL, University of Chicago Press.

Rabin, M. (1998) 'Psychology and Economics', Journal of Economic Literature, XXXVI, $11-46$.

Rotter, J. B. (1966) 'Generalized Expectations for Internal vs. External Control', Psychological Monographs, 80, 1 -28.

Säve-Söderbergh, J. (2010) 'Who Lets Ethics Guide His Economic Decision-making? An Empirical Analysis of Individual Investments in Ethical Funds', Economic Letters, 107, $270-272$.

Schapp, W. (1953) In Geschichten verstrickt: Zum Sein von Ding und Mensch, Hamburg, Richard Meiner.

Schimank (2005) Die Entscheidungsgesellschaft: Komplexität und Rationalität der Moderne, Wiesbaden, VS.

Schmidt, R. (2001) 'Fundamentalanalyse'. In Wirtschaftslexikon, vol. 04, Stuttgart, SchäfferPoeschel, pp. $1983-1992$.

Shiller, R. (2002) 'Bubbles, Human Judgment, and Expert Opinion', Financial Analysts Journal, 58, $18-26$.

Streeck, W. and Mertens, D. (2010) An Index of Fiscal Democracy, MPIfG Working Paper 10/3, Cologne, Max Planck Institute for the Study of Societies.

Svetlova, E. (2009) 'Komplexität an den Finanzmärkten. Das Beispiel des Portfoliomanagements'. In Weyer, J. and Schulz-Schaeffer, I. (eds) Management komplexer Systeme: Konzepte für die Bewältigung von Intransparenz, Unsicherheit und Chaos, München, Oldenbourg, pp. $185-199$.

Thibaud, P. (1985) 'The Triumph of the Entrepreneur', Telos, 64, 134 - 140.

Tigges, C. (2009, February 7) 'Der Ruhestand muss warten', Frankfurter Allgemeine Zeitung, p. 13.

Wärneryd, K.-E. (2001) Stock-Market Psychology: How People Value and Trade Stocks, Cheltenham, Edward Elgar.

White, H. (1992) Identity and Control: A Structural Theory of Social Action, Princeton, NJ, Princeton University Press.

Windolf, P. (2005) 'Was ist Finanzmarkt-Kapitalismus?'. In Windolf, P. (ed.) FinanzmarktKapitalismus. Analysen zum Wandel von Produktionsregimen, Wiesbaden, VS, pp. 20-57.

Zola, E. (1976 [1891]) Das Geld, Berlin-Ost, Rütten \& Loening. 